\title{
Steam Power Plant Performance Operating at High Temperature and Pressure Conditions
}

\author{
${ }^{1}$ A.R.Habbo Mohammed, ${ }^{2}$ Maan S. Al-Dabbagh \\ ${ }^{1,2}$ Mechanical Engineering Department, College of Engineering, University of Mosul, Almajmoa, Mosul 41200, Iraq
}

\begin{abstract}
Steam power plants have been used for generating electric power since early 20 century; their cycles have been subjected to extensive studies in order to improve their performance including power output, thermal efficiency and specific steam consumption etc.

The aim of this work is to examine several configurations based on Rankin cycle to obtain optimum cycle performance. However, four different configurations have been studied including simple Rankine cycle, Ideal regenerative Rankine cycle, Ideal regenerative-reheat cycle and finally regenerative - reheat cycle with intermediate steam extraction for high pressure turbine.
\end{abstract}

Two cases have been considered in current study; the first case was carried out when the turbine pressure is assumed to be constant at 80 bar and the temperature varies from $300^{\circ} \mathrm{C}$ to $700^{\circ} \mathrm{C}$. The second case was studied when turbine inlet pressure varies from 35 to 120 bars and the temperature of steam entering turbine is kept constant at $480{ }^{\circ} \mathrm{C}$.

$\begin{array}{ll}\text { Nomenclature: } \\ \mathrm{Cp} & \text { Specific heat at constant pressure }(\mathrm{kJ} / \mathrm{kg} \mathrm{K}) \\ \mathrm{Cv} & \text { Specific heat at constant volume }(\mathrm{kJ} / \mathrm{kg} \mathrm{K}) \\ \mathrm{S} & \text { Entropy }(\mathrm{kJ} / \mathrm{kg}) \\ \text { s.s.c. } & \text { Specific steam consumption }(\mathrm{kg} / \mathrm{kW} . \mathrm{h}) \\ \mathrm{H} & \text { Enthalpy }(\mathrm{kJ} / \mathrm{kg}) \\ \cdot & \text { Mass flow rate }(\mathrm{kg} / \mathrm{s}) \\ m & \\ \dot{Q} & \text { Heat flow rate }(\mathrm{kW}) \\ \text { T.I.T } & \text { Turbine inlet temperature }\left({ }^{\circ} \mathrm{C}\right) \\ \text { T.I.P. } & \text { Turbine inlet pressure }(\mathrm{bar}) \\ \text { Wratio } & \text { Work ratio, WR }=\mathrm{W}_{\text {net }} / \mathrm{W}_{\mathrm{t}} \\ \eta_{\text {th }} & \text { Thermal efficiency }(\%)\end{array}$

\section{INTRODUCTION}

A steam power plant plays a big role in producing electric power throughout the world. Therefore improving its performance would lead to increase the power output, thermal
Regarding to the first case, the obtained results reflects that the configuration of regenerative - reheat with intermediate steam extraction has a better performances which involve high thermal efficiency, low specific steam consumption, and very high work ratio. Results show that thermal efficiency increases nearly by $(4.77 \%)$, while the specific steam consumption reduced nearly by $(\mathbf{1 0 . 2 2 \%})$, and finally work ratio improved nearly by $(0.08 \%)$ in comparison with simple cycle, when inlet turbine temperature increase from 300 to $700{ }^{\circ} \mathrm{C}$.

However, in the second case, the turbine inlet pressure increases from 35 to 120 bar (temperature of superheated steam is $480^{\circ} \mathrm{C}$ ). Results show the thermal efficiency increase nearly by (2.42\%), Specific steam consumption improved nearly by $(\mathbf{7 . 6 5 \%})$, and finally work ratio decreased nearly by $(0.12 \%)$.

Keywords: Thermal power plant, Rankine cycle, Regenerative Rankine cycle.

Subscripts:

$\begin{array}{cl}\text { 1-4 } & \text { Number of states } \\ \text { B } & \text { Boiler } \\ \text { Cond. } & \text { Condenser } \\ \text { L } & \text { Liquid } \\ \text { P } & \text { Pump } \\ \text { s.t } & \text { Steam turbine } \\ \text { Tur. } & \text { Turbine } \\ \text { Vol. } & \text { Volumetric } \\ \text { Vap } & \text { vapor } \\ \mathrm{y}_{1} & \text { Fraction enclosing the closed heater } \\ \text { y, } \mathrm{y}_{2} & \text { Fraction enclosing the open feed water heater }\end{array}$

efficiency, work ratio and in addition to that reducing the cost of the unit power.

In early days of producing electric power by steam power plants, they were operating on a simple Rankine cycle mode 
ISSN (online): 2581-3048

Volume 5, Issue 7, pp 81-90, July-2021

https://doi.org/10.47001/IRJIET/2021.507014

and surely they had low thermal efficiency. Figs. 1a and $1 \mathrm{~b}$ shows the schematic diagram and $\mathrm{T}-\mathrm{S}$ diagram of simple Rankine cycle. However in order to overcome this problem to enhance the performance of steam power plant, reheat and regenerative cycle modes have been introduced to be applied individually or entirely. The suggested regenerative Rankin cycle with one open feedwater heater is shown in Fig. 2, it consist of Boiler, turbine, condenser, feedwater pump and one open feedwater heater.

In regenerative reheat cycles, steam will expand firstly in high pressure turbine to a certain pressure and then directed back to be reheated before entering the low pressure turbine. , as shown in Figs. 3 and 4. The optimum reheating pressure is about one - fourth the maximum cycle pressure [1].

In reheat - regenerative cycle mode, as shown in Figs 3 and 4. Superheated steam leaving the boiler at very high temperature and pressure (boiler pressure) enters high pressure turbine, expand to a specific pressure which some steam at this state is extracted and directed to a feedwater heater. Clearly many studies have been carried out to investigate various methods and techniques to improve the performance of steam power plants.

Ch. Vijaya kumer et. al. [2], curried out theoretical study on steam power plant to study the effect of increasing the number of feedwater on the performance. He claims that the efficiency of power plant increase with increasing number of heaters, but it is not economical to have large number of feedwater heater. His result shows that having 6 to 7 feedwater heaters in 210 MW, plant would increase the efficiency by 5 to $6 \%$ approximately. However the maintenance must be increase, therefore, it's not worth to have such number of feedwater heater.

Kirankumar Kulkarni et. al. [3], develops a computer program to compare the performance of reheat and regenerative steam power cycle. His results showed that regenerative cycle is more efficient compared to reheat cycle.
Moreover, for a given set of operating conditions, combined cycle has highest efficiency and simple Rankine cycle has least efficiency.

Ivan sunit Rout et. al. [4], investigated the parameters that can affect the performance of steam plant. He stated that the turbine inlet temperature played a very vital rule in the performance in the steam power plant.

Pedro F. Arce. et. al. [5], developed a computer program in MATLAB software with an interface (Graphical Unit Interface, GUI) to simulate many configurations of Rankine cycles, which providing the user all values of the main parameters of these processes. He found that the developed program provides good results showing and can be used to improve the function of the equipments in these thermodynamic cycles.

\section{MATHEMATICAL MODEL}

Obviously, a simple steam power plant (based on Rankin cycle) consist of a boiler to generate a superheated steam , a steam turbine to produce work due to thermal expansion of steam , a condenser to convert steam to saturated water and a feed pump to raise the condensate water boiler pressure [6], as shown in Fig. 1. However, in a cogeneration steam power plant, feedwater heaters either open or closed feedwater heaters are used to improve the performance of the cycle as shown in Figs. 2, 3 and 4.

\subsection{Boiler}

As it has been mentioned earlier, the function of boiler is to generate a superheated steam to desired temperature and pressure to produce a super heated steam at maximum pressure in the cycle. Hence, the amount of heat supplied can be obtained as follows according to cycle configuration: simple, ideal regenerative Rankine cycle, ideal regenerativereheat cycle and finally regenerative - reheat cycle with intermediate steam extraction. The heat supplied for each one can be obtained as follows:

- Simple Rankine cycle: the amount of heat supplied can be determined by the following equation

$$
\mathrm{Q}_{2-4}=\dot{m}\left(\mathrm{~h}_{4}-\mathrm{h}_{2}\right) \quad(\mathrm{kJ})
$$

Or per unit mass

$$
\mathrm{q}_{2-4}=\left(\mathrm{h}_{4}-\mathrm{h}_{2}\right) \quad(\mathrm{kJ} / \mathrm{kg})
$$

- Ideal regenerative Rankin cycle : the amount of heat supplied per unit mass is given as follows:

$\mathrm{q}_{1-7}=\left(\mathrm{h}_{1}-\mathrm{h}_{7}\right)$

- Ideal regenerative - reheat Rankin cycle : the amount of heat supplied per unit mass is given as follows: 
$\mathrm{q}_{\text {total }}=\mathrm{q}_{1-11}+\mathrm{q}_{3-4}=\left(\mathrm{h}_{1}-\mathrm{h}_{11}\right)+\left(1-\mathrm{y}_{1}\right) *\left(\mathrm{~h}_{4}-\mathrm{h}_{3}\right)$

- $\quad$ Regenerative - reheat cycle with intermediate steam extraction:

$$
\mathrm{q}_{\text {total }}=\mathrm{q}_{1-11}+\mathrm{q}_{3-4}=\left(\mathrm{h}_{1}-\mathrm{h}_{11}\right)+\left(1-\mathrm{y}_{1}-\mathrm{y}_{2}\right) *\left(\mathrm{~h}_{4}-\mathrm{h}_{3}\right)
$$

\subsection{Steam turbine}

The primary function of a steam turbine is to produce work as a result of thermal expansion of steam. The work out put can be obtained according to cycle configuration.

- Simple Rankin cycle: the amount of work output be determined by the following equation

$\mathrm{W}_{\mathrm{st}}=\mathrm{W}_{4-5}=\dot{m} *\left(\mathrm{~h}_{5}-\mathrm{h}_{4}\right) \quad(\mathrm{kJ})$

Or per unit mass:

$$
\mathrm{w}_{\mathrm{st}}=\left(\mathrm{h}_{5}-\mathrm{h}_{4}\right) \quad(\mathrm{kJ} / \mathrm{kg})
$$

- Ideal regenerative Rankin cycle: the amount of work output per unit mass is given as follows:

$$
\mathrm{w}_{\mathrm{st}}=\mathrm{w}_{\mathrm{s} . \mathrm{t} 1}+\mathrm{w}_{\mathrm{s} . \mathrm{t} 2}=\left(\mathrm{h}_{1}-\mathrm{h}_{2}\right)+(1-\mathrm{y}) *\left(\mathrm{~h}_{2}-\mathrm{h}_{3}\right) \quad(\mathrm{kJ} / \mathrm{kg})
$$

- Ideal regenerative-reheat Rankin cycle: the amount of work output per unit mass is given as follows:

$$
\mathrm{w}_{\mathrm{st}}=\mathrm{w}_{\mathrm{s.t1}}+\mathrm{w}_{\mathrm{s} . \mathrm{t} 2}=\left(\mathrm{h}_{1}-\mathrm{h}_{2}\right)+\left[\left(\mathrm{y}_{1}\right) *\left(\mathrm{~h}_{4}-\mathrm{h}_{5}\right)+\left(1-\mathrm{y}_{1}-\mathrm{y}_{2}\right) *\left(\mathrm{~h}_{5}-\mathrm{h}_{6}\right)\right] \quad(\mathrm{kJ} / \mathrm{kg})
$$

- $\quad$ Regenerative - reheat Rankin cycle with intermediate steam extraction: the amount of work output per unit mass is given as follows:

$$
\mathrm{w}_{\mathrm{st}}=\mathrm{w}_{\mathrm{s} . \mathrm{t} 1}+\mathrm{w}_{\mathrm{s} . \mathrm{t} 2}=\left[\left(\mathrm{h}_{1}-\mathrm{h}_{2}\right)+\left(\mathrm{y}_{1}\right) *\left(\mathrm{~h}_{2}-\mathrm{h}_{3}\right)\right]+(1-\mathrm{y} 1-\mathrm{y} 2) *\left(\mathrm{~h}_{5}-\mathrm{h}_{6}\right) \quad(\mathrm{kJ} / \mathrm{kg})
$$

\subsection{Condenser}

Steam leaves the turbine and enters the steam condenser at condenser pressure, which starts to condense due to heat transfer between the steam and surrounding. The amount of heat rejected in condenser can be obtained according to cycle configuration using the following equation.

- Simple Rankin cycle: the amount of heat rejected can be determined by the following equation

$\mathrm{Q}_{5-1}=\dot{m} *\left(\mathrm{~h}_{5}-\mathrm{h}_{1}\right)$

Or per unit mass

$$
\mathrm{Q}_{5-1}=\left(\mathrm{h}_{5}-\mathrm{h}_{1}\right) \quad(\mathrm{kJ} / \mathrm{kg})
$$

- Ideal regenerative Rankin cycle : the amount of heat rejected per unit mass is given as follows:

$$
\mathrm{q}_{3-4}=(1-\mathrm{y}) *\left(\mathrm{~h}_{3}-\mathrm{h}_{4}\right) \quad(\mathrm{kJ} / \mathrm{kg})
$$

- Ideal regenerative-reheat Rankin cycle : the amount of heat rejected per unit mass is given as follows: $\mathrm{q}_{6-7}=(1-\mathrm{y} 1-\mathrm{y} 2) *\left(\mathrm{~h}_{6}-\mathrm{h}_{7}\right) \quad(\mathrm{kJ} / \mathrm{kg})$

- $\quad$ Regenerative - reheat Rankin cycle with intermediate steam extraction: the amount of heat rejected per unit mass is given as follows:

$\mathrm{q}_{6-7}=(1-\mathrm{y} 1-\mathrm{y} 2) *\left(\mathrm{~h}_{6}-\mathrm{h}_{7}\right) \quad(\mathrm{kJ} / \mathrm{kg})$ 


\subsection{Feed water pump}

The feed water pump often is used to raise the saturated water leaving the condenser to boiler pressure. Two feedwater heaters open and closed have been used in the cycles; the work of feed water pump can be estimated according to cycle configuration as follows.

- $\quad$ Simple Rankin cycle: the amount of work input is determined by the following equation.

$$
\mathrm{W}_{\mathrm{p}}=\dot{m} \quad\left(\mathrm{~h}_{2}-\mathrm{h}_{1}\right)
$$

Or per unit mass

$$
\mathrm{w}_{\mathrm{p}}=\left(\mathrm{h}_{2}-\mathrm{h}_{1}\right)=\mathrm{v}\left(\mathrm{P}_{2}-\mathrm{P}_{1}\right) \quad(\mathrm{kJ} / \mathrm{kg})
$$

- Ideal regenerative Rankin cycle : the amount of work input per unit mass is given as follows:

$$
\mathrm{w}_{\mathrm{p}}=\mathrm{w}_{\mathrm{p} 1}+\mathrm{w}_{\mathrm{p} 2}=(1-\mathrm{y})\left(\mathrm{h}_{5}-\mathrm{h}_{4}\right)+\left(\mathrm{h}_{7}-\mathrm{h}_{6}\right) \quad(\mathrm{kJ} / \mathrm{kg})
$$

- Ideal regenerative-reheat Rankin cycle : the amount of work input per unit mass is given as follows:

$$
\mathrm{w}_{\mathrm{p}}=\mathrm{w}_{\mathrm{p} 1}+\mathrm{w}_{\mathrm{p} 2}=(1-\mathrm{y} 1-\mathrm{y} 2)\left(\mathrm{h}_{8}-\mathrm{h}_{7}\right)+\mathrm{y} 2\left(\mathrm{~h}_{7}-\mathrm{h}_{6}\right) \quad(\mathrm{kJ} / \mathrm{kg})
$$

- $\quad$ Regenerative - reheat Rankin cycle with intermediate steam extraction: the amount of work input per unit mass is given as follows:

$$
\mathrm{w}_{\mathrm{p}}=\mathrm{w}_{\mathrm{p} 1}+\mathrm{w}_{\mathrm{p} 2}=(1-\mathrm{y} 1-\mathrm{y} 2)\left(\mathrm{h}_{8}-\mathrm{h}_{7}\right)+\mathrm{y} 2\left(\mathrm{~h}_{7}-\mathrm{h}_{6}\right) \quad(\mathrm{kJ} / \mathrm{kg})
$$

Obviously at this point the power output, thermal efficiency, specific steam consumption and work ratio can be obtained as follows

$$
\eta_{\mathrm{th}}=\mathrm{W}_{\mathrm{net}} / \mathrm{Q}_{\mathrm{add}}
$$

Or can be written as follows

$$
\eta_{\mathrm{th}}=\left(\mathrm{w}_{\mathrm{t}}-\mathrm{w}_{\mathrm{p}}\right) / \mathrm{q}_{2-4}
$$

The specific steam consumption, S.S.C. can be obtained according to the following formula

$$
\text { S.S.C. }=\dot{m} * 3600 / \mathrm{W}_{\text {net }} \quad(\mathrm{kg} / \mathrm{kW} . \mathrm{h})
$$

Or can be written as follows

$$
\text { S.S.C }=\text { Steam Production }(\mathrm{kg} / \mathrm{h}) / \text { Power }(\mathrm{kW})
$$

The work ratio (W.R) could be calculated as follows

$$
\mathrm{WR}=\mathrm{W}_{\text {net }} / \mathrm{W}_{\mathrm{t}}
$$

Finally the back work ratio may be found using the following equation

$$
\mathrm{W}_{\mathrm{Rb}}=\mathrm{W}_{\text {net }} / \mathrm{W}_{\mathrm{t}}
$$

The performance of steam power plant either the simple cycle or modified cycle will be obtained with aid of EES (Engineering Equation Solver) which provide the user by all properties of steam at all states.

The value of $\mathrm{y}_{1}$ can be determined by applying the conservation mass and energy equation to control volume of closed feedwater heater resulting in. [7] 
While, $y_{2}$ can be obtained from open feedwater heater.

$$
\mathrm{y}_{2}=\left\{\left(1-\mathrm{y}_{1}\right) * \mathrm{~h}_{8}+\mathrm{y}_{1} * \mathrm{~h}_{13}-\mathrm{h}_{9}\right\} /\left(\mathrm{h}_{8}-\mathrm{h}_{5}\right)
$$

In the otherwise the fraction y for the ideal regenerative Rankine cycle with an open feedwater heater can be determined as the following equation.

$$
\mathrm{y}=\left(\mathrm{h}_{6}-\mathrm{h}_{5}\right) /\left(\mathrm{h}_{2}-\mathrm{h}_{5}\right)
$$

\section{RESULTS AND DISCUSSION}

In the present work, the performances of steam power plant, simple, ideal regenerative - reheat and finally regenerative - reheat with intermediate steam extraction cycles have been studies intensively thermally in order to see the effect of operating parameter, such as temperature and pressure on the performance of a steam power plant.

Clearly, two different cases have been investigated with regarding to the boiler pressure and temperature. In the first case, the boiler pressure is fixed at 80 bar while the boiler temperature varies from 300 to $700{ }^{\circ} \mathrm{C}$. However, the condenser pressure is kept constant at 0.035 bar.

In the second case, the temperature of superheated steam entering the steam turbine is kept constant at $480{ }^{\circ} \mathrm{C}$ while the pressure is varied from 35 to 120 bar which is quite high.

A computer program was developed by the authors and compiles with Engineering Equation Solver (EES) to asses the performance of steam plant [8]. The benefit of having Engineering Equation Solver is to get the thermal properties of the working fluid throughout the whole cycle.

Fig. 5 shows the relationship between the turbine inlet temperature T.I.T and the thermal efficiency for different configuration (Simple, Regenerative, Regenerative - reheat and finally regenerative - reheat at intermediate extraction cycles). Clearly it can be seen that the thermal efficiency increases as the turbine steam inlet temperature for all study configuration. And surely because heat constants of the superheated; steam increases as the turbine inlet increasing. Moreover, steam cycle with regenerative - reheat with intermediate steam extraction show a higher thermal efficiency.

Fig. 6 shows the relationship between the turbine inlet temperature and specific steam consumption for the same configuration which mentioned previously. Examining; figure (6). It can be noted that as the turbine inlet temperature increase, the specific steam consumption decreases. This may be regard as the heat content in steam increase with temperature which results in decreasing specific steam consumption.

Fig. 7 shows the relationship between the work ratio and turbine inlet temperature. It can be seen that the value of work ratio nearly constant. This is may be due to a small work is required by the feedwater pump to rise the condense water to boiler pressure pump in comparison to the value of work given by the steam turbine for all four cases.

However, in order to investigate the effect of boiler temperature on the performance of steam power plant, turbine inlet temperature is kept constant at $480^{\circ} \mathrm{C}$ while the boiler pressure is varied from $35-120$ bar.

Fig. 8 shows the relationship between the turbine inlet pressure (boiler pressure) and thermal efficiencies of all configurations. All configuration show similar pattern and behavior, which show that thermal efficiency, increase as turbine pressure increase but one with intermediate extraction giver a higher efficiency.

Examining Fig. 9, it can be noted that the specific steam consumption decrease as turbine pressure increases for all studied configuration, however, the simple cycle mode gives the least specific steam consumption because in the Rankine cycle with reheat and regenerative- reheat cycle steam coming out of high pressure turbine is reheated and given to the low pressure turbine. Fuel utilization increase before it is to be condensed in condenser. More work output is obtained from same amount of fuel so consumption decreases.

Finally, the relationship between turbine inlet pressure and work ratio is pictured in Fig. 10. Obviously, the work ratio seems to be constant for each cycle mode but the one with intermediate extraction indicate the lower ratio.

\section{CONCLUSION}

In the present study, results indicate that the performance of steam power plants can be improved by applying modified cycle mode to basic Rankine cycle. Obviously, these modifications involve regenerative cycle, reheat - regenerative cycle with different location in steam extraction $[9,10]$, from 
ISSN (online): 2581-3048

the obtained results, a conclusion can be summarized into the following point:

1. Regenerative - reheat cycle with intermediate steam extraction give a high thermal efficiency (47.23\%) at case 1 and $(44.36 \%)$ at case 2 as compared to simple and regenerative steam power plants. Obviously thermal efficiency increase nearly by $(4.77 \%)$ relatively to other, low specific steam consumption in comparison with other.

2. Results also show that simple cycle plant has low thermal efficiency, high specific steam consumption.

3. The work ratio decrease as the turbine inlet temperature increase and show the minimum value for regenerative cycle.

4. The effect of turbine inlet temperature and turbine pressure was obvious and shows a positive effect throughout all considered cases.

Finally, the current study showed that configuration of regenerative - reheat with intermediate extraction is more efficient as compare to simple regenerative, regenerative reheat steam power plants. The thermal efficiency improves and specific steam consumption decrease.

\section{Highlights:}

- A theoretical study for steam power plant was conducted.

- Steam intermediate extraction from high pressure turbine.

- Thermal efficiency was increased by $2.42 \%$.

- Specific steam consumption improved by $7.65 \%$.

\section{REFERENCES}

[1] Cengel, Y.A. , and Boles , M.A. , (2006) ,"Thermodynamics an Engineering Approach", Fifth edition in SI units, McGraw Hill.

[2] Ivan Sunit Rout, Abhishek Gaikwad, Vinod Kumar Verma, Mohammad Tariq, (May. - Jun. 2013), "Thermal Analysis of Steam Turbine Power Plants", IOSR Journal of Mechanical and Civil Engineering
(IOSR-JMCE) e-ISSN: 2278-1684,p-ISSN: 2320334X, Volume 7, Issue 2, PP 28-36.

[3] Ch.vijaya kumar, Dhananjaya Kumar M.E., (MarApr. 2014), "Performance Analysis of Regenerative Feed Heating in A Steam Power Plant", IOSR Journal of Mechanical and Civil Engineering (IOSRJMCE) e-ISSN: 2278-1684,p-ISSN: 2320-334X, Volume 11, Issue 2 Ver. V, PP 01-08.

[4] Kirankumar Kulkarni, M.R.Nagaraj,( 2016), "Comparative Performance of Reheat and Regenerative Steam Cycle by using Program”, IJSRD - International Journal for Scientific Research \& Development| Vol. 4, Issue 06, ISSN (online): 23210613.

[5] Pedro F. Arce. , Nian F. Vieira, (January 2017), "Thermodynamic Simulation of Steam Power Cycles using GUI MatLab Interfaces", Int. Journal of Engineering Research and Application, www.ijera.com ISSN: 2248-9622, Vol. 7, Issue 1, ( Part -3), pp.88-93.

[6] Bhatt, M. S. and Rajkumar, N. (1999), "Performance enhancement in coal fired thermal power plants". Part II: steam turbines. Int. J. Energy Res., 23: 489515. doi: $10.1002 \quad /($ SICI $) 1099$ 114X(199905)23:6489::AID-ER 494>3.0.CO;2-T.

[7] Moran, M.J., Shapiro. H.N., (2006) "Fundamentals of Engineering Thermodynamics". The Ohio State University Iowa State University of Science and Technology, John Wiley \& Sons Ltd.

[8] Klein S.A., (2013) "Engineering Equation Solver", Laboratory of Thermodynamic University of Lige, Belgium.

[9] Srinivas, T., Gupta, A., Reddy, B.V., (2007), "Generalized Thermodynamic Analysis of Steam Power Cycle with Number of Feedwater Heater, International Journal of Thermodynamic 10 (4): 177 185.

[10] Qian Zhu, (March 2015), IEA Clean Coal Center High-efficiency power generation - review of alternative systems. London SW18 1DD, United Kingdom.

\section{Citation of this Article:}

A.R.Habbo Mohammed, Maan S. Al-Dabbagh, "Steam Power Plant Performance Operating at High Temperature and Pressure Conditions" Published in International Research Journal of Innovations in Engineering and Technology - IRJIET, Volume 5, Issue 7, pp 81-90, July 2021. Article DOI https://doi.org/10.47001/IRJIET/2021.507014 

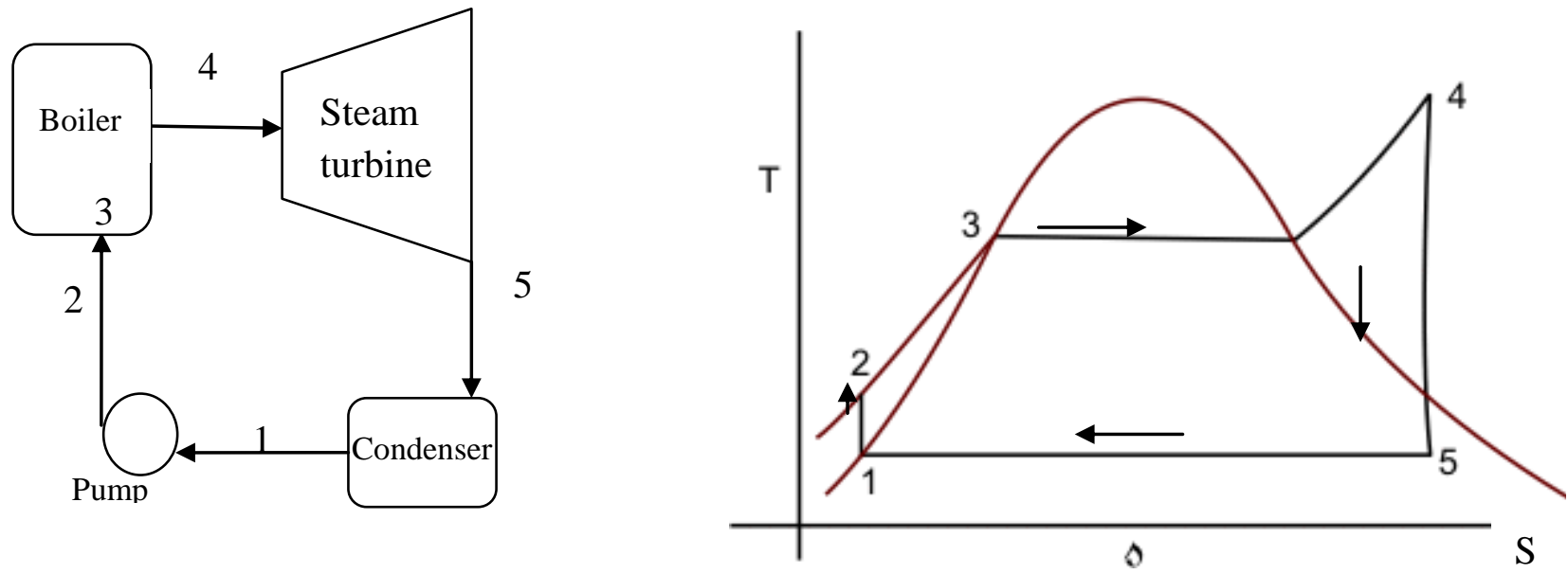

Figure (1-a): Simple Rankine cycle

Figure (1-b): T - S diagram for simple Rankine cycle

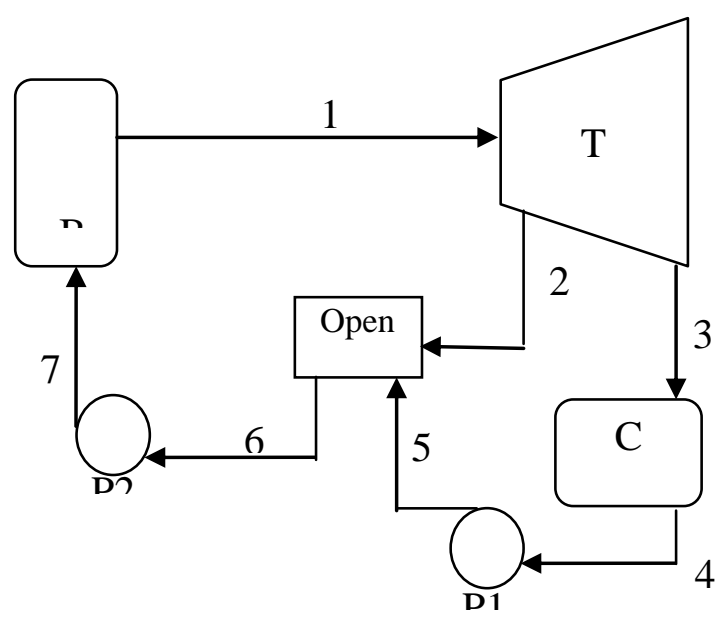

Figure (2:) The ideal Regenerative Rankine cycle with an open feedwater heater

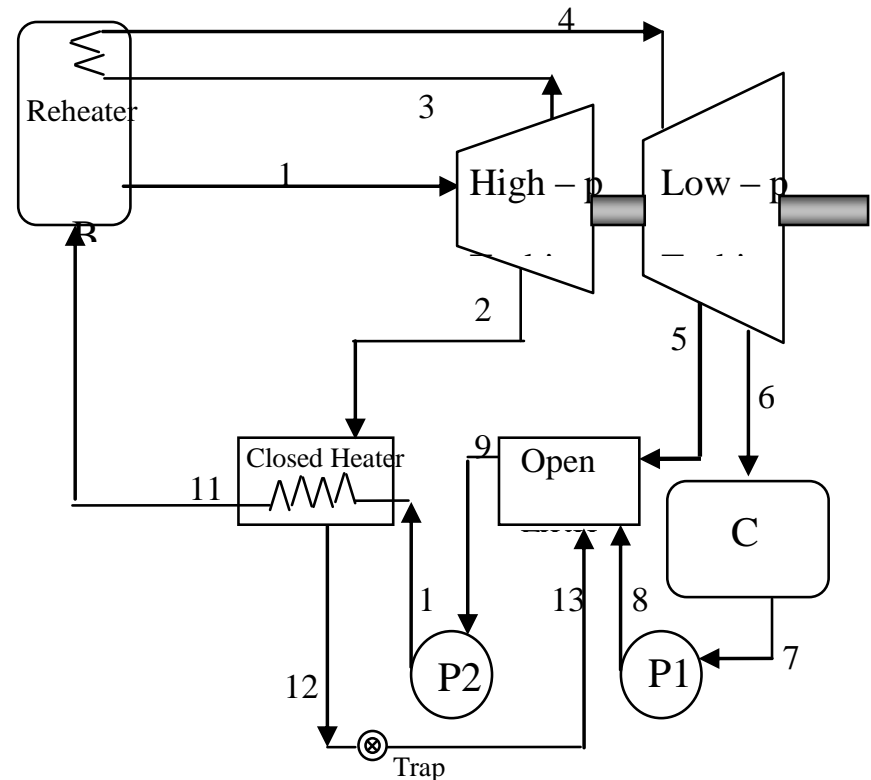

Figure (3): The ideal Regenerative Rankine cycle with closed and open feedwater heater

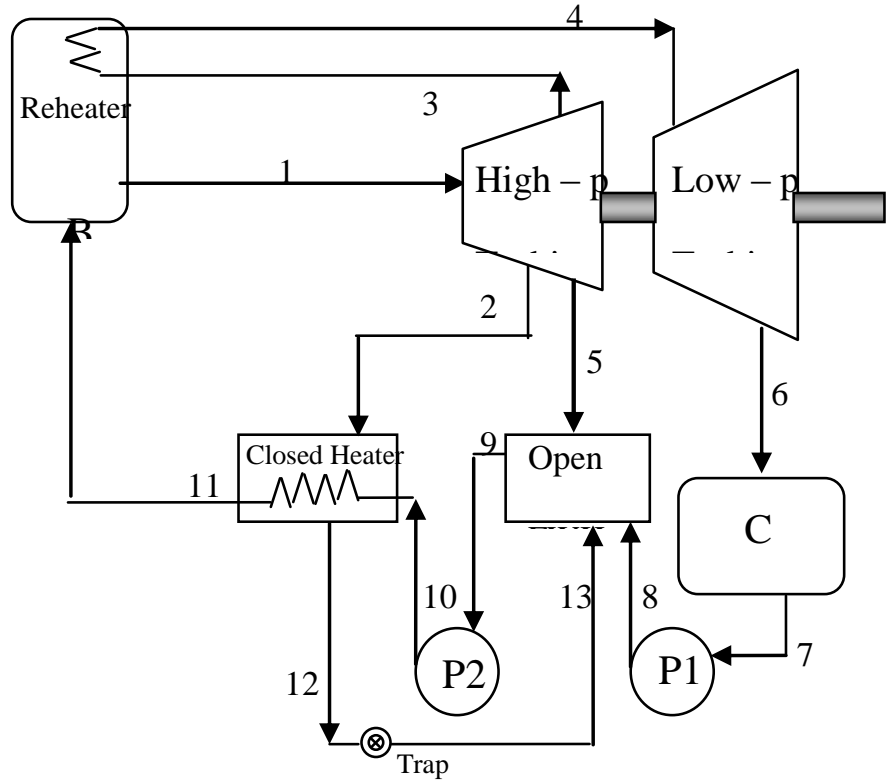

Figure (4): The ideal Regenerative Rankine cycle with closed and open feedwater heater (intermediate case) 


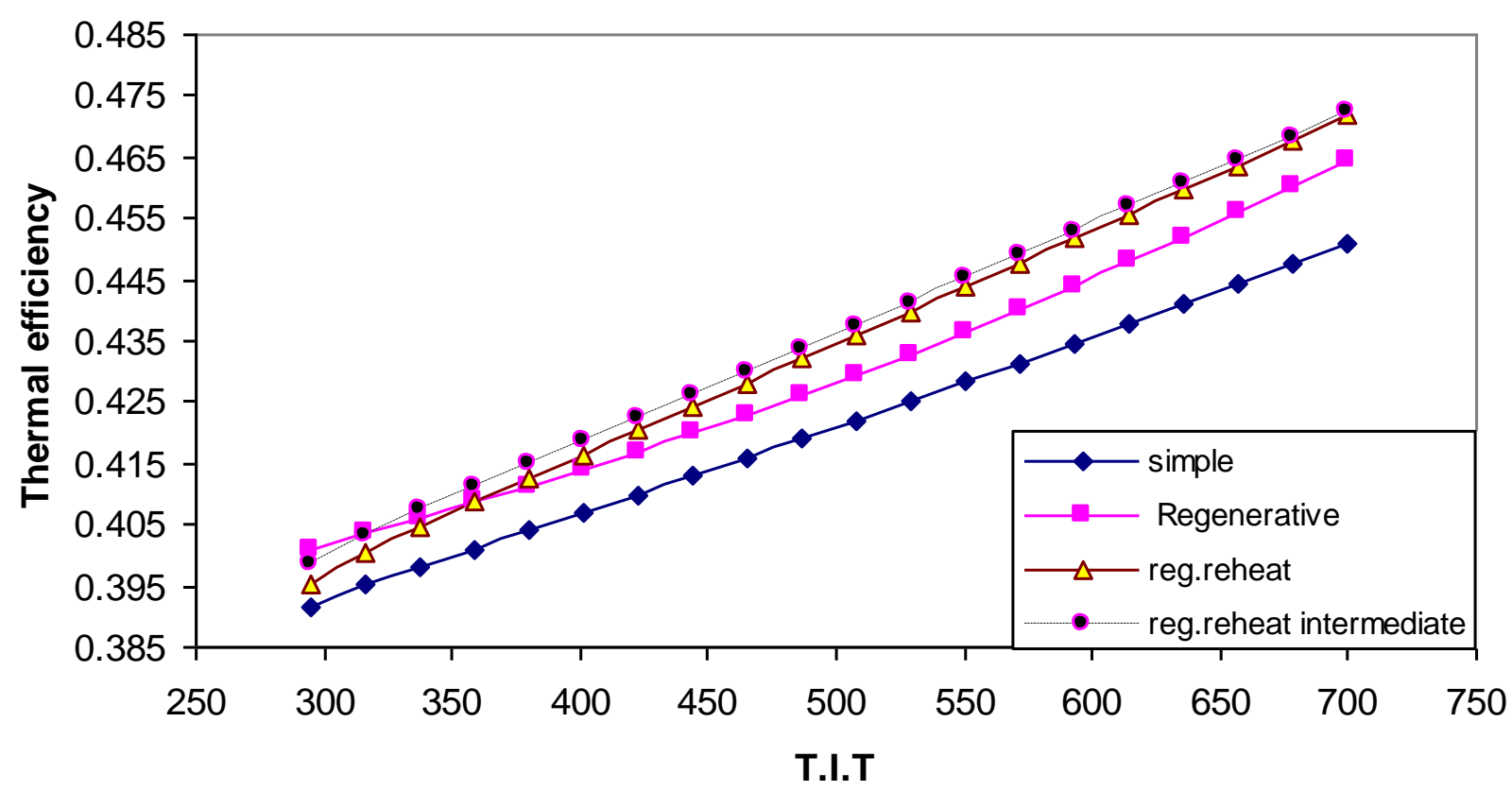

Figure (5): Relation between thermal efficiency and turbine inlet temperature

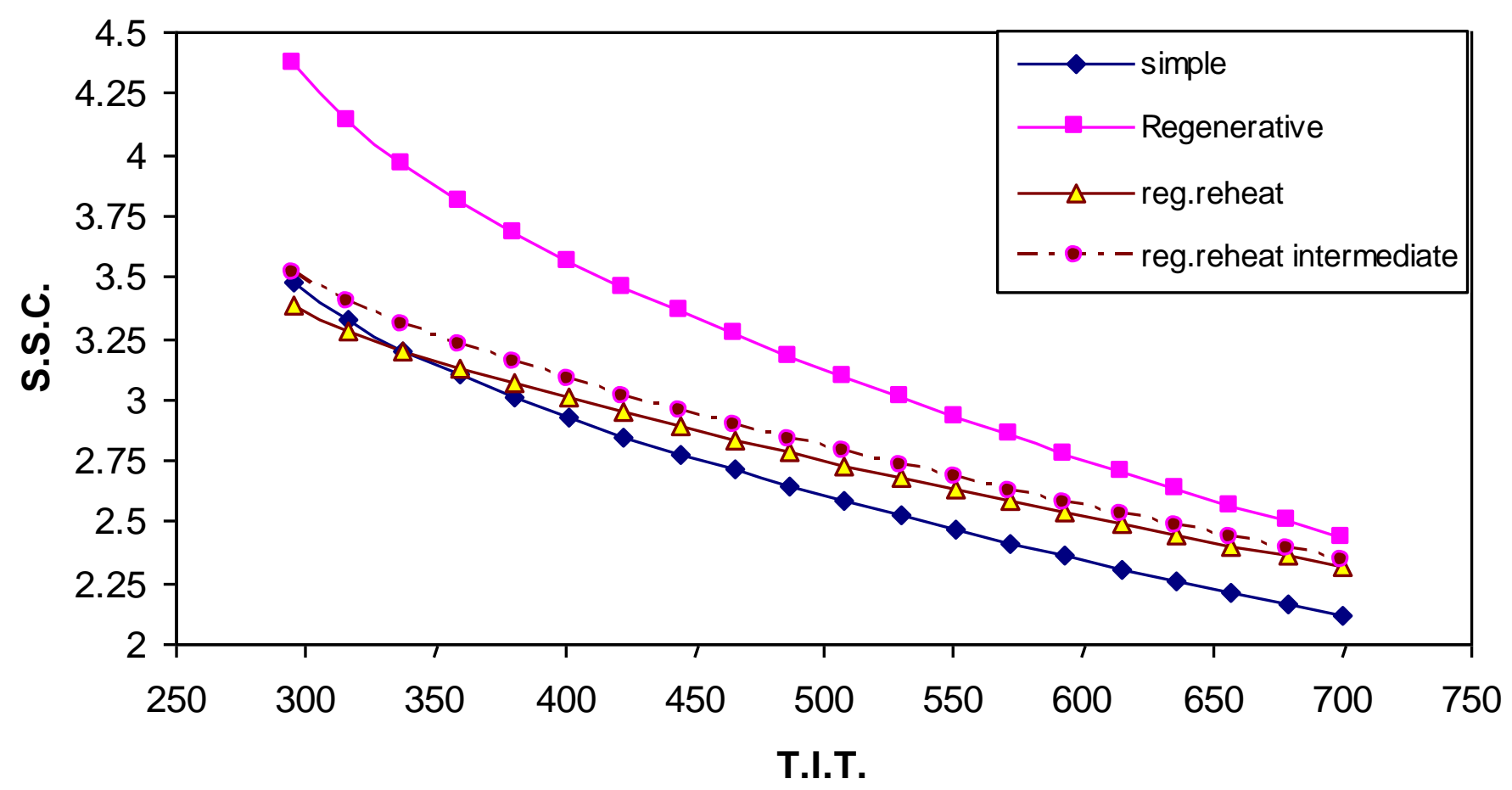

Figure (6): Relation between specific stream consumption and turbine inlet temperature 


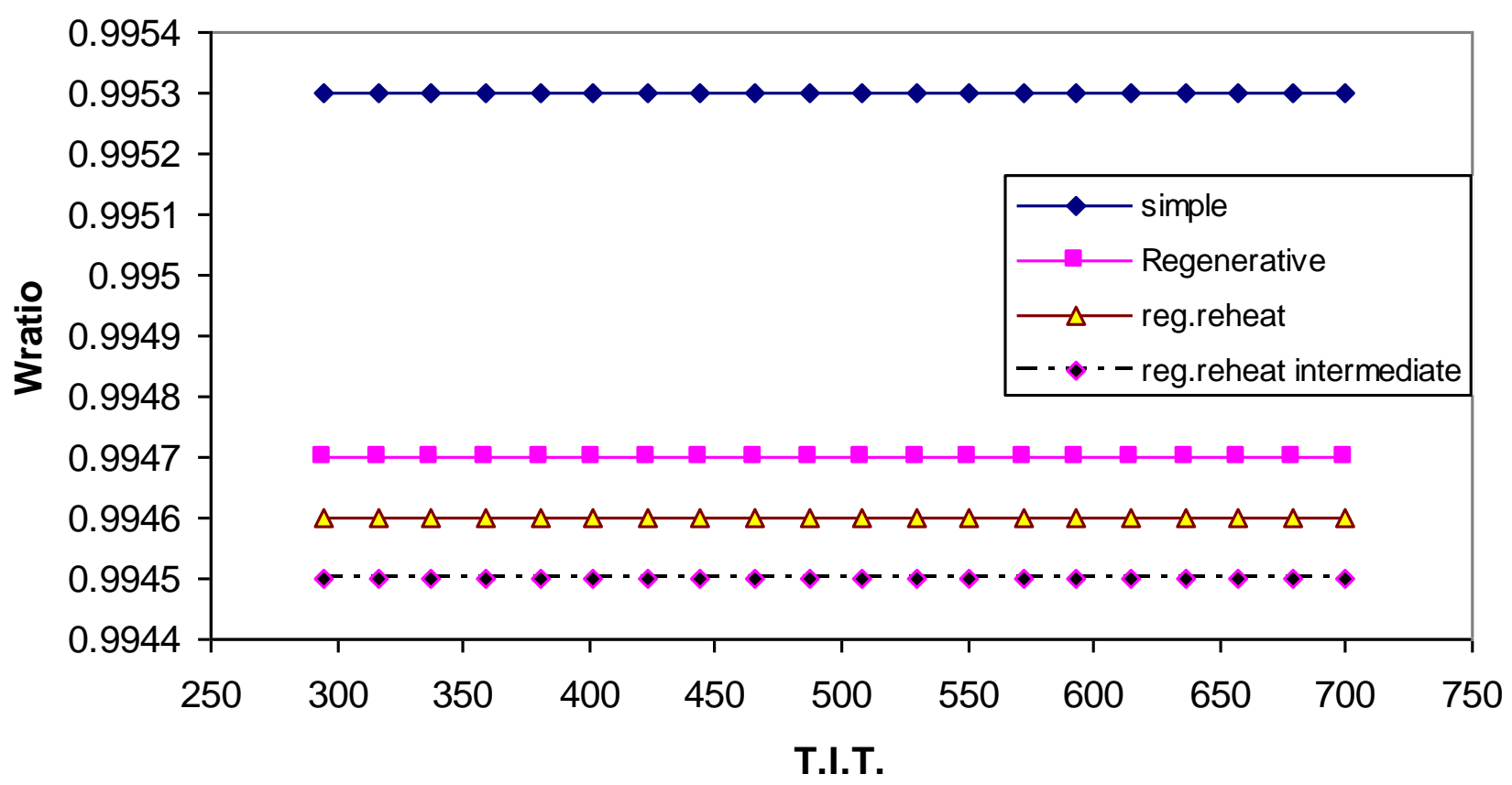

Figure (7): Relation between work ratio and turbine inlet temperature

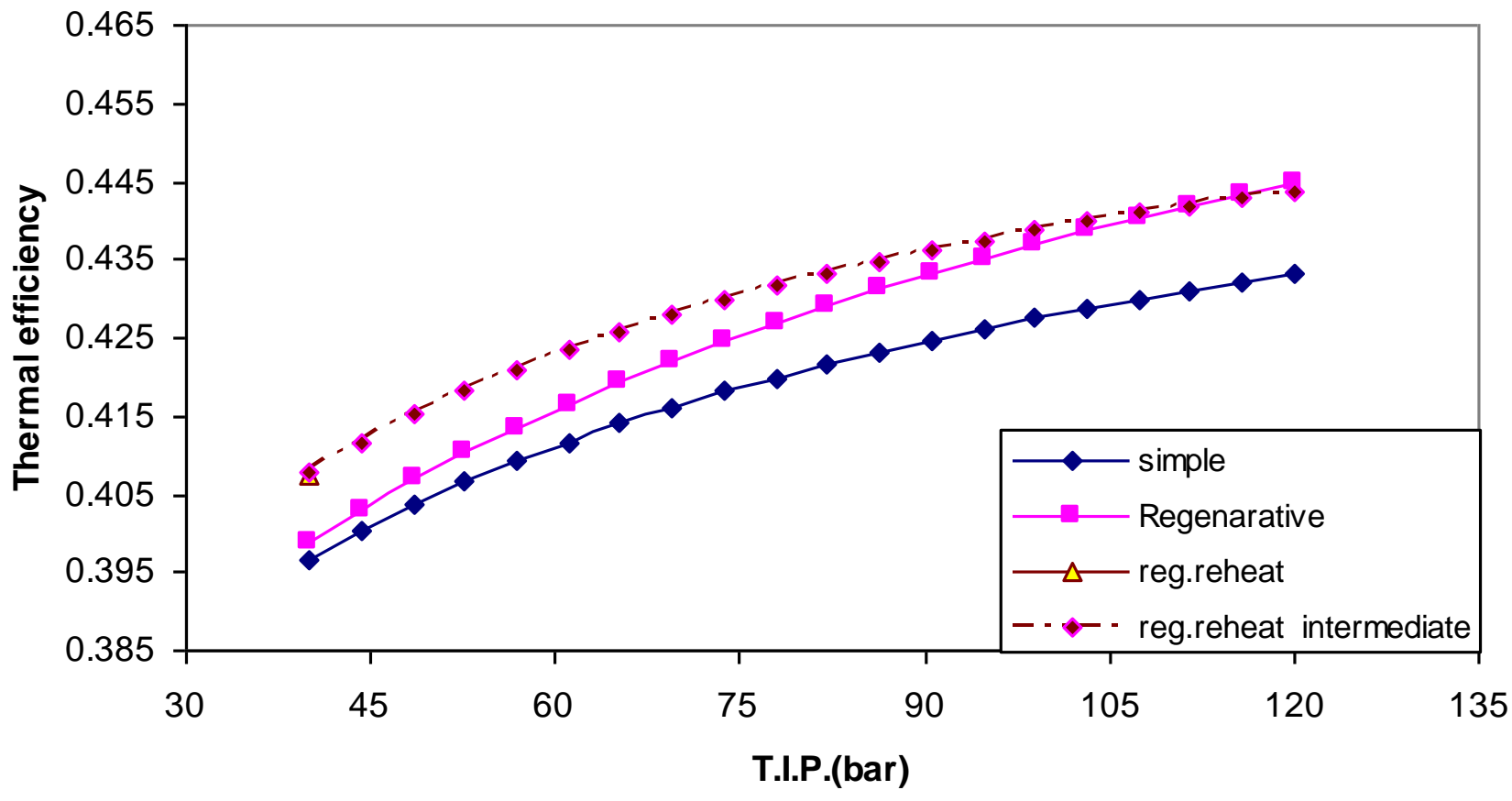

Figure (8): Relation between thermal efficiency and turbine inlet pressure 


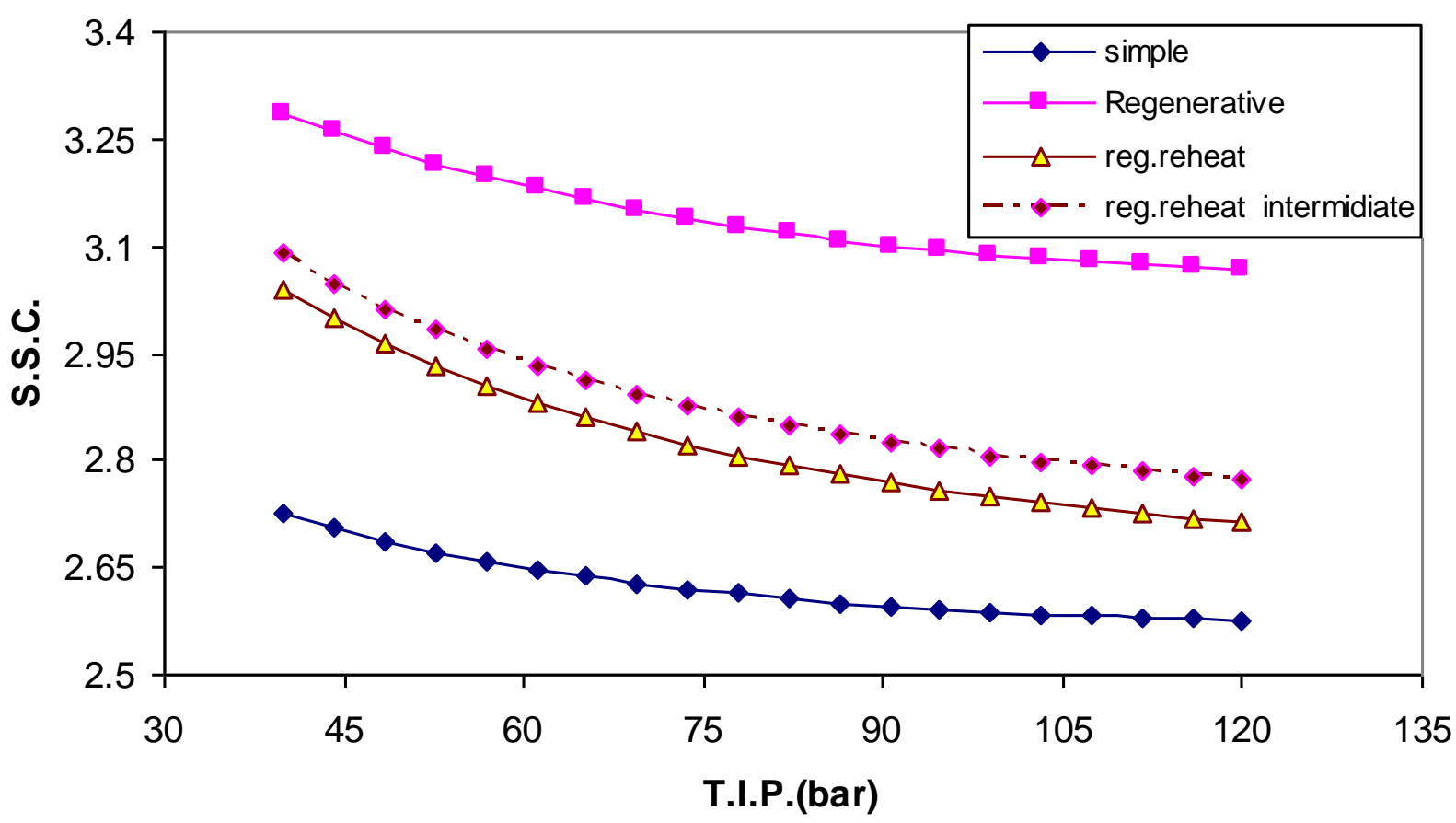

Figure (9): Relation between specific steam consumption and turbine inlet pressure

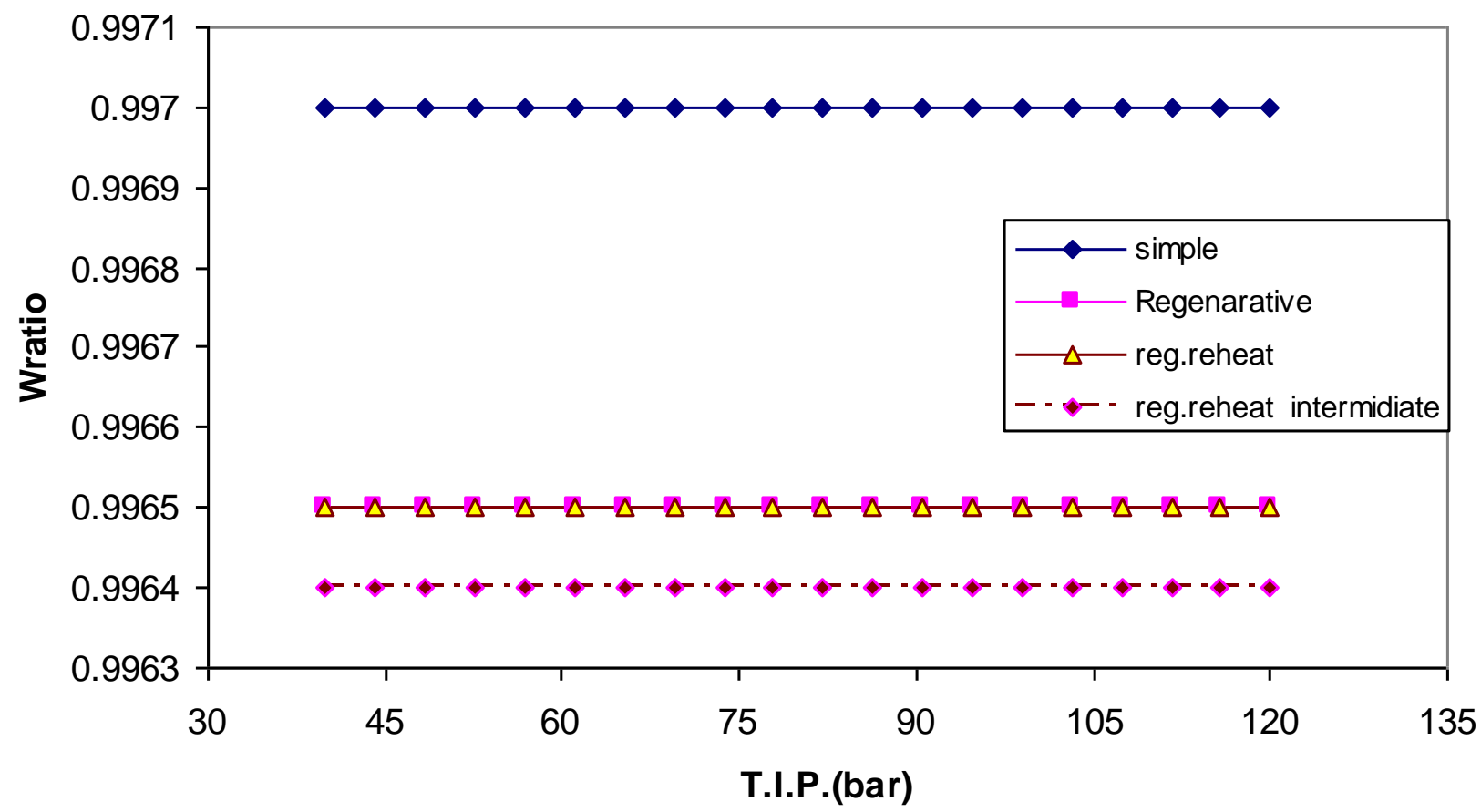

Figure (10): Relation between work ration and turbine inlet pressure 